\title{
PERAN WANITA MUSLIM DALAM MEMINIMALISIR KEKERASAN DALAM RUMAH TANGGA
}

\author{
Patmawati dan Fitri Sukmawati \\ Dosen Fakultas Ushuluddin Adab dan Dakwah \\ Institut Agama Islam Negeri Pontianak \\ Email: fwati1974@gmail.com \\ ghandur@yahoo.com
}

\begin{abstract}
Islam is the graceful religion that gives the rules towards women about how they act to their husband in domestic environment in order to build the togetherness fairly. Not to mention in the marriage life, the roles of wives are very important. They should behave politely, sweetly, kindly, and full of love and trust to their husband. Besides, a wife also should try to possess the adorable acts towards the husband. Moreover, as a mother for her children, a woman should also able to afford the rights and obligations to the children based on their physical dan psychological development, so that the children could contribute to the religion, country, and their nation.
\end{abstract}

Keywords: Moslem woman, Violence, Household and Domestic environment

\section{PENDAHULUAN}

Hak-hak asasi wanita telah mencapai tingkat signifikansi yang tinggi di era modern pada umumnya dan di dunia Islam pada khususnya. Secara historis, perempuan selalu berada di bawah laki-laki. Kaum wanita sering dianggap sebagai makhluk the second sex sebagaimana yang dijelaskan oleh Simon de Beauvoir. Namun demikian, semua kesan tersebut telah mengalami perubahan yang sangat cepat. Proses liberalisasi perempuan telah mencapai signifikan baru, khususnya setelah Perang Dunia Kedua (PD II) (Asghar Ali Engineer, 2003: 12).

Kris Budiman (1999: 122) mengutip alKitab mengatakan bahwa Tuhan menciptakan wanita (Hawa) dari tulang rusuk lelaki (Adam) sebagai afterthought, untuk menjadi penolong atau supelmen pria (periksa Kitab Kejadian, 2: 21-23). Tetapi, peranan yang rendah ini kini ditolak oleh semakin banyak wanita. Status wanita berbeda-beda sepanjang zaman. Bila diukur dengan kekuatan dan partisipasinya dalam kehidupan sosial dan intelektual masyarakat, status mereka agak tinggi pada akhir kekaisaran Romawi, kemudian sangat menurun dengan penyebaran agama kristen”, begitu kata Horton dan Leslie, mengawali tulisannya tentang diskriminasi seks sebagai masalah sosial. Orang boleh setuju atau tidak dengan pendapatnya. Tetapi yang jelas, pandangan bahwa wanita adalah makhluk rendah bukan milik orang Yahudi saja. Kongfucu (Confucius) menyatakan bahwa ada dua jenis manusia yang sukar diurus, yaitu turunan orang rendahan dan wanita. Aristoteles, tokoh logika terkenal itu, malah menyebut wanita sebagai manusia yang belum selesai, yang tertahan dalam perkembangan tingkat bawah (Jalaluddin Rahmat, 1986: 124). Bahkan dalam ideologi patriarki, secara tegas disebutkan bagaimana bentuk kekuasaan laki-laki terhadap perempuan, yang pada akhirnya juga memasuki ruang negara. Dengan demikian, tampaknya pihak negara dan semua kebijakannya masih menunjukkan upaya mengukuhkan ideologi patriarki dalam berbagai kebijakannya. Selain dalam konsep perkawinan, juga dalam bidang organisasi dan pemerintahan (Zohra Andi Baso, 2000: 8).

Pada zaman jahiliah, wanita juga menempati posisi yang sangat terhina, dia tidak memiliki hak untuk memperoleh warisan bahkan dapat diwariskan oleh suaminya kepada anak- 
anaknya dari wanita lain. Jadi, tidak mengherankan apabila Umar bin Khattab khalifah kedua dalam perjalanan sejarah Islam, pernah mengubur anak perempuannya karena memiliki anak perempuan merupakan aib keluarga. Wanita juga tak dapat diandalkan dalam peperangan padahal pada masa itu peperangan antara klan atau suku, sesuatu yang sering terjadi. Al-Quran merekam peristiwa jahiliah dalam peringatan abadi, "apabila bayi-bayi perempuan yang dikubur hiduphidup itu ditanya; karena dosa apakah dia dibunuh" (QS 81: 8-9).

Dengan datangnya Islam, praktek seperti ini dihilangkan bahkan wanita memiliki kedudukan yang utama dan terhormat. Wanita dipandang sama dengan pria dalam tanggung jawab agamawi, sosial, dan patriotik, tetapi berbeda dengan para suami dalam urusan keluarga. Ia tidak dapat dipaksa kawin oleh keluarga atau walinya, ia harus memberikan persetujuannya. Dalam keluarga, ia boleh mempertahankan nama gadisnya. Ia sungguh-sungguh independen dalam hal finansial dan dapat berbuat dengan uangnya menurut kehendaknya, sementara si suami (atau ayah atau saudara lelaki) bertanggungjawab untuk menafkahinya maupun anak-anaknya. Dalam hal warisan, sebagai anak perempuan ia mendapatkan setengah dari bagian saudara lelakinya, tetapi dalam situasi lain ia mendapatkan sama banyak atau bahkan lebih banyak daripada lelaki dalam keluarganya. Sebagai ibu, ia ditempatkan di atas suaminya dalam hal kesetiaan dan kasih sayang anak-anaknya. Ia diberi hak istimewa untuk berbicara membela hakhaknya (dalam batas kesopanan tradisional Islam) (Abd. Al-Rahim Umran, 1997: 45).

Will Durant (Jalaluddin Rahmat,1986: 125), seorang pencatat sejarah umat manusia, menulis tentang jasa nabi Muhammad dalam meningkatkan dan memperbaiki hak-hak wanita atau sekarang dikenal dengan istilah gender. Oleh karena itu gender dalam Islam sudah diperkenalkan dan dipraktekkan sejak masa Nabi Muhammad.

Pada masa nabi Muhammad beberapa wanita merasa prihatin bahwa pria mungkin akan mengambil bagian yang lebih besar dalam membangun tatanan moral dan sosial Islam. Misalnya, pria biasa pergi kepada Nabi dan berbaiat kepada beliau. Para wanita itu bertanya apakah mereka boleh ikut mendapatkan hak ini. Nabi menyediakan suatu hari khusus bagi wanita dan al-Quran memberikan kepada mereka hak yang sama (Abd al-Rahim Umran, 1997: 51).

"Hai Nabi, apabila datang kepadamu yang perempuan-perempuan beriman untuk mengadakan janji setia, bahwa mereka tidak akan mempersekutukan sesuatu pun dengan Allah, tidak akan mencuri, tidak akan berzina, tidak akan membunuh anak-anaknya, tidak akan berbuat dusta yang mereka ada-adakan antara tangan dan kaki mereka, dan tidak akan mendurhakaimu dalam urusan yang baik, maka terimalah janji setia (bai'ah) mereka dan mohonkanlah ampunan kepada Allah untuk mereka...(QS. Al-Mumtahanah: 12).

Nabi juga mengizinkan kaum wanita mendatangi masjid, walaupun di rumah lebih baik. Apabila wanita hadir bersama bayinya untuk mendengarkan ceramah nabi, maka nabi akan memperlakukan mereka dengan baik bahkan disaat ceramahpun apabila dia mendengarkan suara bayi, ceramahnya akan disingkat sehingga sang ibu bayi tidak risau dengan suara anaknya. Nabi menghentikan praktek pembunuhan terhadap bayi oleh orang-orang Arab. Dia menyamakan wanita dengan pria dalam hal hukum dan kebebasan finansial. Wanita boleh memiliki profesi apa saja, mewarisi kekayaan orang tuanya, dan menggunakan uangnya sesuai dengan keinginannya. Dia juga telah menghapus adat Arab mewariskan kaum wanita kepada anak laki-lakinya. (Jalaluddin Rahmat, 1986: 125).

Mansour Faqih dalam Rianawati (2001: 79) mengatakan bahwa persamaan kedudukan laki-laki dan perempuan tidak hanya dalam bidang agama, tetapi juga dalam pengambilan 
keputusan dan ekonomi, yaitu untuk memiliki harta kekayaan dan tidaklah suami atau bapaknya boleh mencampuri hartanya. Kekayaan itu termasuk yang didapat melalui pewarisan ataupun yang diusahakannya sendiri. Oleh sebab itu, mahar atau mas kawin dibayar oleh laki-laki untuk pihak perempuan sendiri, bukan untuk orang tua dan tidak bisa diambil kembali suaminya.

Pandangan Durant ini telah menegaskan adanya pengakuan sejarawan Barat tentang kedudukan wanita yang tinggi setelah kehadiran Islam. Melihat perkembangan dan pesoalan sekarang, banyak sekali peranan wanita yang penting dan berpengaruh terhadap kehidupan di rumahnya maupun di lingkungan masyarakatnya baik wanita itu bekerja ataupun tidak. Ditulisan ini akan dijelaskan kedudukan wanita dalam kehidupan sosial menurut Islam, dipersempit lagi wanita dan pergaulan yang meliputi: pergaulan dalam rumahtangga, pergaulan dengan masyarakat, dan pergaulan di masa pendidikan dan sekolah. Persoalan dibatasi hanya menurut pandangan Islam, bukan berarti meremehkan pandangan agama lain terhadap kaum wanita, hal ini dilakukan kerena pertimbangan praktis dari penulis yang memang keilmuannya masih terbatas dalam lingkup Islam.

\section{WANITA DAN PERGAULAN}

Status wanita dalam Islam telah dipahami secara parah karena banyak sebab. Adalah suatu kesalahan ketika perilaku kaum Muslim individual maupun komunal dijadikan cerminan dari hukum dan ortodoksi Islam. Ini digandakan lagi oleh salah pengertian tentang status wanita dalam Islam, atau penyalahgunaan secara kasar atas hukum keluarga Islam di kalangan sebagian kelompok Muslim yang tidak mengetahui. Umat muslim tidak boleh mengabaikan faktor keterbelakangan di beberap negara, situasi yang umumnya berkaitan dengan status wanita yang rendah bukan hanya di negara-negara Muslim melainkan juga di negara-negara non-Muslim Dunia ketiga (Abd al-Rahim Umran, 1997: 45-46).

Di sisi lain, beberapa penulis muslim berbuat kesalahan karena bias yang merugikan. Dalam gairah mereka untuk membuktikan kemoderenan Islam, mereka hanya memilih komponen-komponen yang menyejajari sistem-sistem Barat. Distorsi ini hanya menyajikan sebagian dari totalitas yang merupakan kultur Islam. Berbeda dengan kepercayaan umum, Islam mengangkat status wanita dan memberikan kepadanya hak manusiawi, sipil, sosial, dan ekonomi yang sebelumnya tidak pernah diberikan kepada wanita. Sama dengan pria, wanita muslim mempunyai kepribadian yang merdeka dalam kewajiban yang agamawi, dalam hak atas pendidikan, dalam ganjaran atas amal-amalnya, maupun dalam membela keyakinannya. Ia mempunyai hak yang sempurna dan total atas semua miliknya. Ia bebas memilih pasangan kawinnya, dan mempunyai hak untuk menuntut kekuasaan menceraikan, plus kekuasaan pada waktu akad nikah untuk tidak mengizinkan suaminya melakukan poligami. Juga, ia dapat mempertahankan nama gadisnya setelah kawin, apabila ia menghendaki. Ia juga bertanggungjawab atas keluarganya, tetapi si lelaki yang mempunyai tanggung jawab utama (Abd al-Rahim Umran, 1997: 46).

Membahas tentang wanita dan pergaulannya dalam pandangan Islam tidaklah terlepas daripada aqidah, budi dan akhlak. Tujuan pokok dari agama Islam ialah memperbaiki budi pekerti umat manusia. Sabda Rasulullah: "aku ini diangkat semata-mata untuk memperbaiki budi-akhlak yang mulia” (HR. Baihaqi dari Abu Hurairah).

Kelebihan dan perbedaan manusia daripada jenis makhluk yang lain, ialah manusia itu bilamana bergerak, maka gerak dan geriknya itu timbul dari dalam, bukan datang dari luar. Segala 
usaha, pekerjaan, langkah yang dilangkahkan, semuanya itu timbul daripada suatu maksud yang tertentu dan datang dari suatu perasaan yang paling tinggi, yang mempunyai kuasa penuh di dalam dirinya (Hamka, 1972: 11)

Keberhasilan nabi Muhammad dalam merubah keadaan dari masyarakat yang jahiliah, tidak ada norma-norma dan etika, manusia hidup tak obahnya laksana hewan, menjadi masyarakat yang beradab, tidak terlepas dari akhlak beliau yang memang terpuji dan dapat menjadi contoh tauladan. Ahli-ahli sejarah di luar Islam yang menyelidiki secara seksama dan objektif kehidupan serta perjuangan nabi Muhammad saw. Semuanya berkesimpulan, mereka kagum terhadap nilainilai kepemimpinan (leadership) yang terdapat pada diri beliau, serta yang terutama dan sangat menonjol ialah tentang budi dan akhlak yang menjiwai segala bidang hidup dan perjuangannya (Pimpinan Pusat Muhammadiyah Majlis Tarjih, 1972:8).

Jadi, akhlak ialah sikap yang digerakkan oleh jiwa sehingga melahirkan tindakan dan perbuatan, yang dengan akhlak itu manusia akan menempati posisi yang paling utama di antara semua makhluk. Sebagai seorang muslim hendaklah memiliki akhlak yang sempurna sehingga dapat melaksanakan tugas dan kewajibannya, baik sebagai hamba yang taat beribadah kepada Allah maupun sebagai khalifah yang aktif mengambil peran mengatur dan menata kehidupan secara islami sehingga terwujud rahmatan lil alamin di muka bumi ini (Patmawati, tt., 1).

Seorang muslim akan selalu menjaga dirinya, agar tidak terperosok ke dalam perbuatan yang tercela, yang akan membawa kepada suatu tempat yang asfala saafilin (QS. At-Tien: 5) "kemudian kami kembalikan dia ke tempat yang serendah-rendahnya". Oleh karena itu akhlak dalam Islam sangat perlu dimiliki oleh umat Islam dalam rangka menciptakan kerukunan dan kedamaian. Sehingga lahirlah sopan santun yang menjelma menjadi kasih sayang, tumbuhnya ikatan persaudaraan yang berpadu dengan ketulusan serta keikhlasan yang berdasarkan perikemanusiaan. Dari ini pulalah terwujudnya pergaulan yang mesra dengan landasan harga menghargai, hormat menghormati yang melimpah menyeruak ke setiap rumah tangga, masyarakat dan bangsa yang akan membawa bahagia dan sejahtera serta keselamatan dunia akhirat (Pimpinan Pusat Muhammadiyah Majlis Tarjih, 1972:9).

\section{PERGAULAN DALAM RUMAH TANGGA}

Islam mempunyai suatu karakter sosial yang mendasar, dan keluarga adalah inti masyarakatnya. Islam cenderung memandang keluarga sebagai sesuatu yang mutlak baik dan mendekati suci. Di samping memberikan ketentraman dan dukungan timbal balik dan saling pengertian antara suami istri, fungsi yang jelas dari keluarga adalah memberikan saluran kultural dan legal yang dapat diterima dalam memuaskan naluri seksual maupun untuk membesarkan anak sebagai generasi baru. Namun Islam mempunyai peranan yang lebih hakiki bagi keluarga. Dalam sistem keluarga itulah kaum muslim mendapatkan pembinaan agama, mengembangkan watak moralnya, menegakkan hubungan sosial yang akrab, dan memelihara kesetiaan, baik kepada keluarga maupun kepada masyarakat pada umumnya. Sistem dukungan dalam keluarga (finansial, sosial, maupun emosional) samalah artinya dengan menegakkan ketenangan pikiran dan keamanan yang diperlukan bagi perjalanan hidup. Ini terutama penting bagi para anggota yang bergantung secara sosial, yakni anak, orangtua, dan orang sakit (cacat) (Abd al-Rahim Umran, 1997:11) 
Keluarga dalam Islam meliputi inti keluarga (suami, istri, dan anak mereka), dan varitasvaritas yang meluas yang mencakup semua kerabat (abb). Ada hukum-hukum khusus yang mengatur hubungan keluarga khususnya hubungan suami istri.

Ulama ortodoks juga muslim konservatif menyatakan bahwa peran perempuan benarbenar terbatas di rumah. Kewajiban utamanya adalah mengurus suami dan anak-anaknya. Dia tidak dibolehkan keluar rumah kecuali atas izin suami atau ayahnya dan dia harus ditemani oleh muhrimnya.

Ketaatan kepada suami menjadi suatu keharusan bagi perempuan muslim dan konsep ketaatan ini semakin lama semakin ketat. Konsep ketaatan tersebut menjadi begitu kaku sehingga menurut salah seorang penulis Persia dikutip oleh Asghar Ali Engineer (2003: 295): seorang perempuan ideal, jarang berbicara dan tertawa dan tidak melakukan sesuatu tanpa sebab. Dia tidak pernah meninggalkan rumah, bahkan untuk bertemu tetangga atau kenalan. Dia tidak memiliki teman sesama perempuan, tidak memberikan kepercayaan kepada siapapun, dan suaminya adalah satu-satunya kepercayaannya. Dia tidak menerima apapun dari orang lain, kecuali suami dan orang tuanya. Jika dia menemui kerabat-kerabatnya, dia tidak mencampuri urusanurusan mereka. Dia tidak berhianat, dan tidak memiliki kesalahan yang disembunyikan, bahkan tidak memiliki alasan-alasan buruk untuk diajukan. Dia tidak mencoba menarik perhatian orangorang. Jika suaminya menunjukkan niatnya melakukan ritus perkawinan, dia setuju dengan hasrathasrat suaminya dan kadang-kadang membangkitkannya. Dia membantu suaminya dalam segala urusannya, dan sedikit mengeluh dan menangis; dia tidak tertawa atau gembira ketika dia melihat suaminya sedang murung atau berduka, tetapi memikul bersama kesulitan-kesulitannya, dan memancingnya untuk tertawa, hingga dia ceria lagi. Dia tidak menyerahkan dirinya kepada siapapun selain suaminya. Perempuan seperti itu dihargai oleh siapapun” dalam kehidupannya.

Hubungan suami istri dalam perkawinan digambarkan dalam Al-Quran sebagai dua kualitas pokok: cinta (birahi, persahabatan, pertemanan) di satu sisi, dan rahmah (pengertian, kedamaian, toleransi, dan saling memaafkan) di sisi lain, dalam tujuan menyeluruh berupa ketentraman. Al-Quran menyebutkan "dan di antara tanda-tanda kekuasaanNya ialah Dia menciptakan untukmu istri-istri dari jenismu sendiri, supaya kamu cenderung dan merasa tentram kepadanya, dan dijadikan-Nya di antara kamu kasih dan sayang...(QS. Ar-Rum: 21).

Ayat di atas sering dikutip dalam menggambarkan salah satu tujuan kehidupan rumah tangga. Dimulai dengan merujuk ke kesatuan asal suami dan istri, yang merupakan suatu pengukuhan tentang persamaan dan basis bagi keselarasan di antara mereka. Maka kemudian menyusul dengan sendirinya ketentraman (sakinah) yang akan didapatkan oleh suami dan istri. Ayat kunci ini menyimpulkan dengan merujuk kepada hubungan sosial di dalam keluarga, yang berkisar dari cinta dan kelembutan kepada pengertian, sayang dan belas kasih(Abd al-Rahim Umran, 1997: 12)

Allah SWT menciptakan wanita untuk lelaki dan menjadikannya sebagai istrinya; bukan hanya untuk memadamkan kobaran syahwat seksual yang ada padanya, atau hanya sebagai sebab untuk meneruskan tali keturunan, tetapi Allah menciptakannya -mulanya dan sebelum segala sesuatu- sebagai sumber kemantapan bagi lelaki dan tempat ketenangan (agar kamu merasa tentram kepadanya). Seorang lelaki yang mendapatkan seorang istri yang salehah, dan seorang wanita yang mendapatkan seorang suami yang saleh, keduanya tidak akan menemukan pada kehidupannya melainkan ketetapan hati dan ketenangan jiwa. Rumah tangga semacam ini akan 
jauh dari faktor-faktor kegelisahan dan kegoncangan yang berbahaya (Husain Mazhahiri, 2002: 108-109).

Islam telah memberikan tuntunan kepada kaum wanita bagaimana mereka harus bertindak terhadap suaminya dalam pergaulan rumah tangga, untuk dapat menciptakan kehidupan bersama yang utama dan serasi. Maka apa yang harus dilakukan oleh wanita terhadap suaminya adalah sebagai berikut: wanita yang menjadi istri, harus bersikap patuh, taat serta senantiasa hormat terhadap suaminya. Isteri harus bersikap sopan santun, bermanis muka, ramah tamah, dengan menampakkan kecintaan dan kepercayaan yang penuh terhadap suami. Seorang isteri juga berusaha untuk memiliki gaya dan daya penarik serta tambatan hati bagi suaminya. Menghormati kedua orang tua sendiri dan kedua orang tua suami adalah suatu kewajiban utama yang dipikulkan kepada setiap wanita Islam (Pimpinan Pusat Muhammadiyah Majlis Tarjih, 1972: 12-13).

Seorang wanita Islam yang telah bersuami, yang telah beranak khususnya yang telah menjadi ibu rumah tangga, memikul pula suatu kewajiban utama dalam pergaulan sehari-hari terhadap anaknya. Menurut para ahli di bidang Pendidikan dan Kejiwaan adalah harus berlandaskan tujuan untuk mendidik dengan sifat kasih sayang, karena anak-anak adalah amanah Tuhan. Orang tualah yang membentuknya akan jadi apa mereka. Khususnya kaum ibu yang sangat memegang peranan penting dalam membentuk kepribadian anak, karena ibu merupakan orang yang terdekat dengan mereka.

Islam memandang posisi keibuan wanita sebagai posisi paling penting. Dalam beberapa ayat Al-Quran yang menyuruh agar berbuat baik kepada orang tua. Al-Quran menekankan dan mengingatkan kesusahan ibu dalam mengandung dan menyusui anak (QS 31: 14; dan QS 46: 15). Ketika Nabi SAW ditanya tentang siapa yang paling patut dihormati dan diperlakukan sebaikbaiknya, Nabi menjawab: "Ibumu". Dan hal ini diulangnya sampai tiga kali, sebelum ia menyebut "bapakmu". Dalam hadis lain yang masyhur, Nabi saw berkata bahwa surga terletak di bawah telapak kaki kaum ibu. Kepada rahim kaum wanitalah, Allah menitipkan janin yang lembut dan lemah di saat-saat pengembangannya. Walaupun ayah dan ibu menyumbangkan bagian yang sama dalam pembentukan nucleus ovum, namun ibu memberikan semua protoplasma yang mengelilingi nukleus (Jalaluddin Rahmat, 1986: 131).

Fenomena sekarang banyak juga wanita atau ibu mendapatkan perlakuan yang tidak menyenangkan baik dirumah maupun lingkungan luar rumah. Tindakan tidak menyenangkan ini yang sering disebut dengan kekerasan terhadap perempuan. Kekerasan dalam Rumah Tangga (KDRT) yang tertuang dalam Undang-undang No. 23 Tahun 2004 tentang Penghapusan Kekerasan Dalam Rumah Tangga, memiliki arti setiap perbuatan terhadap seseorang terutama perempuan, yang berakibat timbulnya kesengsaraan ataupenderitaan secara fisik, seksual, psikologis, dan/atau penelantaran rumah tangga termasuk ancaman untuk melakukan perbuatan, pemaksaan, atau perampasan kemerdekaan secara melawan hukum dalam lingkup rumah tangga.

Masalah kekerasan dalam rumah tangga telah mendapatkan perlindungan hukum dalam Undang-undang Nomor 23 tahun 2004 yang antara lain menegaskan bahwa:

1. Bahwa setiap warga Negara berhak mendapatkan rasa aman dan bebas dari segala bentuk kekerasan sesuai dengan falsafah Pancasila dan Undang-undang Republik Indonesia tahun 1945. 
2. Bahwa segala bentuk kekerasan, terutama Kekerasan dalam rumah tangga merupakan pelanggaran hak asasi manusia, dan kejahatan terhadap martabat kemanusiaan serta bentuk deskriminasi yang harus dihapus.

3. Bahwa korban kekerasan dalam rumah tangga yang kebanyakan adalah perempuan, hal itu harus mendapatkan perlindungan dari Negara dan/atau masyarakat agar terhindar dan terbebas dari kekerasan atau ancaman kekerasan, penyiksaan, atau perlakuan yang merendahkan derajat dan martabat kemanusiaan.

4. Bahwa berdasarkan pertimbangan sebagai dimaksud dalam poin diatas perlu di bentuk Undang-undang tentang penghapusan kekerasan dalam rumah tangga.

Tindak kekerasan yang dilakukan suami terhadap isteri sebenarnya merupakan unsur yang berat dalam tindak pidana, dasar hukumnya adalah KUHP (Kitab Undang Undang Hukum Pidana) pasal 356 yang secara garis besar isi pasal yang berbunyi: "Barangsiapa yang melakukan penganiayaant terbadap ayah, ibu, isteri, atau anak diancam bukuman pidana”.

\section{BENTUK-BENTUK KEKERASAN DALAM RUMAH TANGGA}

Menurut Undang-Undang No. 23 Tahun 2004 tindak kekerasan terhadap istri dalam rumah tangga dibedakan kedalam 4 (empat) macam yaitu:

\section{Kekerasan fisik}

Kekerasan fisik adalah perbuatan yang mengakibatkan rasa sakit, jatuh sakit atau luka berat. Prilaku kekerasan yang termasuk dalam golongan ini antara lain adalah menampar, memukul, meludahi, menarik rambut (menjambak), menendang, menyudut dengan rokok, memukul/melukai dengan senjata, dan sebagainya. Biasanya perlakuan ini akan nampak seperti bilur-bilur, muka lebam, gigi patah atau bekas luka lainnya.

\section{Kekerasan psikologis / emosional}

Kekerasan psikologis atau emosional adalah perbuatan yang mengakibatkan ketakutan, hilangnya rasa percaya diri, hilangnya kemampuan untuk bertindak, rasa tidak berdaya dan / atau penderitaan psikis berat pada seseorang. Perilaku kekerasan yang termasuk penganiayaan secara emosional adalah penghinaan, komentar-komentar yang menyakitkan atau merendahkan harga diri, mengisolir istri dari dunia luar, mengancam atau menakut-nakuti sebagai sarana memaksakan kehendak.

\section{Kekerasan seksual}

Kekerasan jenis ini meliputi pengisolasian (menjauhkan) istri dari kebutuhan batinnya, memaksa melakukan hubungan seksual, memaksa selera seksual sendiri, tidak memperhatikan kepuasan pihak istri.

\section{Kekerasan ekonomi}

Setiap orang dilarang menelantarkan orang dalam lingkup rumah tangganya, padahal menurut hukum yang berlaku baginya atau karena persetujuan atau perjanjian ia wajib memberikan kehidupan, perawatan atau pemeliharaan kepada orang tersebut. Contoh dari kekerasan jenis ini adalah tidak memberi nafkah istri, bahkan menghabiskan uang istri. 


\section{FAKTOR-FAKTOR PENYEBAB KEKERASAN DALAM RUMAH TANGGA}

Strauss A. Murray mengidentifikasi hal dominasi pria dalam konteks struktur masyarakat dan keluarga, yang memungkinkan terjadinya kekerasan dalam rumah tangga (marital violence) sebagai berikut:

\section{Pembelaan atas kekuasaan laki-laki}

Laki-laki dianggap sebagai superioritas sumber daya dibandingkan dengan wanita, sehingga mampu mengatur dan mengendalikan wanita.

\section{Diskriminasi dan pembatasan dibidang ekonomi}

Diskriminasi dan pembatasan kesempatan bagi wanita untuk bekerja mengakibatkan wanita (istri) ketergantungan terhadap suami, dan ketika suami kehilangan pekerjaan maka istri mengalami tindakan kekerasan.

\section{Beban pengasuhan anak}

Istri yang tidak bekerja, menjadikannya menanggung beban sebagai pengasuh anak. Ketika terjadi hal yang tidak diharapkan terhadap anak, maka suami akan menyalahkan istri sehingga tejadi kekerasan dalam rumah tangga.

\section{Wanita sebagai anak-anak}

Konsep wanita sebagai hak milik bagi laki-laki menurut hukum, mengakibatkan keleluasaan laki-laki untuk mengatur dan mengendalikan segala hak dan kewajiban wanita. Laki-laki merasa punya hak untuk melakukan kekerasan sebagai seorang bapak melakukan kekerasan terhadap anaknya agar menjadi tertib.

\section{Orientasi peradilan pidana pada laki-laki}

Posisi wanita sebagai istri di dalam rumah tangga yang mengalami kekerasan oleh suaminya, diterima sebagai pelanggaran hukum, sehingga penyelesaian kasusnya sering ditunda atau ditutup. Alasan yang lazim dikemukakan oleh penegak hukum yaitu adanya legitimasi hukum bagi suami melakukan kekerasan sepanjang bertindak dalam konteks harmoni keluarga.

\section{CARA PENANGGULANGAN KEKERASAN DALAM RUMAH TANGGA}

Menghindari terjadinya Kekerasan dalam Rumah Tangga, diperlukan cara-cara penanggulangan Kekerasan dalam Rumah Tangga, antara lain:

1. Perlunya keimanan yang kuat dan akhlaq yang baik dan berpegang teguh pada agamanya sehingga Kekerasan dalam rumah tangga tidak terjadi dan dapat diatasi dengan baik da npenuh kesabaran.

2. Harus tercipta kerukunan dan kedamaian di dalam sebuah keluarga, karena didalam agama itu mengajarkan tentang kasih sayang terhadap ibu, bapak, saudara, dan orang lain. Sehingga antar anggota keluarga dapat saling mengahargai setiap pendapat yang ada.

3. Harus adanya komunikasi yang baik antara suami dan istri, agar tercipta sebuah rumah tangga yang rukun dan harmonis. Jika di dalam sebuah rumah tangga tidak ada keharmonisan dan 
kerukunan diantara kedua belah pihak, itu juga bisa menjadi pemicu timbulnya kekerasan dalam rumah tangga.

4. Butuh rasa saling percaya, pengertian, saling menghargai dan sebagainya antar anggota keluarga. Sehingga rumah tangga dilandasi dengan rasa saling percaya. Jika sudah ada rasa saling percaya, maka mudah bagi kita untuk melakukan aktivitas. Jika tidak ada rasa kepercayaan maka yang timbul adalah sifatcemburu yang kadang berlebih dan rasa curiga yang kadang juga berlebih-lebihan.

5. Seorang istri harus mampu mengkoordinir berapapun keuangan yang ada dalam keluarga, sehingga seorang istri dapat mengatasi apabila terjadi pendapatan yang minim, sehingga kekurangan ekonomi dalam keluarga dapat diatasi dengan baik.

\section{PERGAULAN DENGAN MASYARAKAT}

Tiap individu mempunyai dua segi hidup. Segi pertama ialah segi terhadap diri sendiri, person, yang bekerja untuk kepentingan dirinya dan bertanggung jawab kepada dirinya sendiri, tidak ada hubungannya dengan orang lain. Segi yang kedua adalah yang berhubungan dengan pergaulan bersama dan masyarakat bersama. Segala pekerjaan yang dikerjakannya hendaklah menjaga akan kepentingan masyarakat, menjaga sopan santun yang dikehendaki oleh pergaulan hidup bersama itu. Sebab dia salah satu di antara anggota masyarakat, maka dirinya tak dapat dipisahkan dari aturan masyarakat. Oleh karena itu individu terikat oleh aturan, adat istiadat yang tidak boleh dilanggar (Hamka,1962: 13).

Islam sudah mengatur pergaulan dalam masyarakat, sebagaimana firman Allah: "wahai orang-orang yang beriman, janganlah merendahkan suatu kaum, sebab boleh jadi adalah yang direndahkan itu lebih baik daripada yang merendahkan, dan jangan pula perempuan berbuat demikian kepada sesamanya perempuan, karena boleh jadi yang direndahkan itu lebih baik daripada yang merendahkan, janganlah kamu memfitnahkan akan dirimu dan jangan kamu memberikan gelaran yang buruk, karena yang seburuk-buruk nama ialah "fasik" sesudah iman, dan barang siapa yang tiada taubat, itulah orang yang aniaya. Wahai orang-orang yang beriman, jauhilah olehmu berbanyak sangka, karena sesungguhnya sebagian sangka itu dosa semata, dan janganlah kamu suka mengintip-intip orang lain, jangan mengumpat, menggunjing setengah kamu kepada yang setengah, adakah seorang di antara kamu suka menelan daging saudaranya yang telah menjadi bangkai, lalu kamu akan benci dia. Dan takutlah kamu sekalian kepada Allah, sesungguhnya Allah itu ialah Tuhan yang menerima taubat dan memberi ampun (QS. Al-Hujurat: 11- 12).

Ayat-ayat ini besar sekali kepentingannya berhubung dengan kesopanan bermasyarakat. Segala keadaan yang dilarang dalam ayat ini, adalah perkara-perkara yang selalu merusakkan masyarakat (Hamka, 1970: 106).

Hubungan pergaulan dengan masyarakat lainnya sesuai dengan kelaziman dan kondisi dimasa kini, dapat dilihat dalam tiga pergaulan: pertama, pergaulan dengan tetangga. Dalam kehidupan suatu masyarakat, terutama yang senantiasa dan lazim terjadi ialah hubungan dan pergaulan dengan tetangga. Mereka inilah yang mengetahui dari dekat hal ihwal seseorang yang menjadi tetangganya, baik dikala senang maupun dikala susah. Kewajiban yang harus diusahakan antara lain: sebagai muslim dengan muslim, dalam segala sikap dan tindak terhadap tetangga harus diusahakan sebagai saudara. Bersikap ramah tamah dan senantiasa lapang dada. Pandai membawa diri, dan menjauhkan diri daripada segala perbuatan yang tercela atau yang menimbulkan 
persengketaan. Mengadakan kunjung mengunjung untuk mengikat tali silaturrahmi yang akan mengokohkan hubungan persaudaraan. Menjenguk dikala sakit dan berusaha menyenangkan hatinya di kala susah. Bantu membantu dalam berbagai hal yang lazim dilakukan di masyarakatnya, mengenai adat istiadat serta tradisi-tradisi setempat yang tidak bertentangan dengan agama, dan terutama dalam hal-hal yang dima'rufkan menurut ajaran Islam.

Kedua, pergaulan dalam bertamu dan menerima tamu. Dalam pergaulan hidup kunjung mengunjungi, bertamu dan menerima tamu suatu keharusan, baik sepanjang adat istiadat, tradisi dan kelaziman di sesuatu masyarakat setempat. Bahkan menurut ajaran Islam, bertamu dan menerima tamu adalah suatu rangkaian dari akhlak (budi pekerti) dan kadang-kadang merupakan suatu ajaran, umpamanya menjenguk orang-orang yang terkena musibah, mengunjungi orangorang tua dan mertua dan lain sebagainya.

Tata cara bertamu yang harus diperhatikan dan dilaksanakan, antara lain: masuk ke sesuatu rumah orang lain atau di sesuatu tempat perjamuan, harus selalu memberi salam, dan atau memberi hormat menurut adat dan tata caranya masing-masing. Harus masuk ke dalam rumah melalui pintu depan, dan diperjamuan melalui pintu atau gerbang yang sengaja disediakan untuk jalan masuk bagi tamu. Melaksanakan sesuatu cara yang diadakan dalam suatu perjamuan, sudah tentu jika cara-cara itu tidak bertentangan dengan Agama Islam. Duduk setelah dipersilahkan, kecuali di rumah kerabat sahabat karib atau keluarga semdiri. Jika ada tamu/orang lain yang datang, hendaklah berdiri sebentar bersalaman dan berkenalan, kemudian duduk kembali.

Adapun tata cara menerima tamu adalah: tamu-tamu harus dihormati sedemikian rupa sesuai dengan derajat dan usianya. Menerima tamu dengan muka manis dan ramah tamah. Memberi kesempatan menyatakan maksud kedatangannya. Diantar sampai ke halaman, meminta maaf jika ada kekurangan dan mengucapkan selamat jalan di saat dia hendak pulang (Pimpinan Pusat Muhammadiyah Majlis Tarjih, 1972: 18-21).

\section{PERGAULAN DI MASA PENDIDIKAN DAN SEKOLAH}

Tiap-tiap orang mempunyai hak untuk belajar (menuntut ilmu), dengan segala tenaga dan usaha serta kecakapannya. Kalau dia tidak mempunyai ilmu, maka hak pertanggung jawab menjadi sia-sia terpegang ditangannya. Penyiaran ilmu dapat menghalangi dijatuhnya hukuman lantaran aniaya. Karena ada orang yang melanggar hukum dengan alasan tidak tahu. Meskipun tidak semua orang sanggup menuntut segala ilmu, namun setiap orang diwajibkan menuntut ilmu dan dimudahkan bagi mereka jalan untuk mencari ilmu, supaya dipilihnya mana yang dia sanggup atau sesuai dengan kekuatan ingatan dan fikirannya (Hamka, 1962: 38).

Di dalam agama Islam, diberi perintah yang sekeras-kerasnya menuntut ilmu itu. Disebutkan bahwa kecerdikan itu adalah cahaya "al-ilmu nuuron" ilmu adalah cahaya, dan kebodohan itu adalah kegelapan. Maka di negeri kita ini, ada beberapa perkumpulan sosial (yang mementingkan soal masyarakat) memberantas buta huruf, sebab sekarang masih ada daerah yang kurang pandai membaca (buta huruf) khususnya dialami kaum wanita. Sehingga kini muncul program pemberantasan buta huruf terhadap wanita dengan program Koran Desa, salah satunya dilaksanakan oleh Pusat Studi Wanita (PSW) STAIN Pontianak (Koran Ibu, 2006).

Adapun pergaulan di masa pendidikan dan sekolah adalah di mana anak-anak bergaul dengan teman-teman seperguruannya yang sebaya, seusia dan pergaulannya itu senantiasa tertentu dan terarah di bawah pengawasan para gurunya. Oleh karena itu menjadi kewajiban orang tua untuk memilih sekolah/madrasah yang dapat menjamin perkembangan keilmuan dan akhlak 
seorang anak, supaya pendidikan dan pergaulan anak-anaknya sesuai dengan ajaran Islam. Kemudian o \rang tua juga harus mempertimbangkan potensi yang ada pada anaknya, sehingga anak dapat menjadi manusia yang bermanfaat bagi keluarga, negara dan agamanya.

Para pendidik/guru atau muaddib dalam Islam memiliki kedudukan yang sangat tinggi, mereka dipandang sebagai "pemimpin" karena selain mentransferkan ilmu pengetahuannya, pendidik juga dituntut membina akhlak seorang anak. Jadi, tidak hanya aspek intelektual semata tetapi juga akhlak sangat diutamakan. Semua ini dapat terlaksana apabila akhlak guru sudah tercermin dalam dirinya melalui tingkah laku sehingga pepatah yang mengatakan "guru kencing berdiri murid kencing berlari" itu tidak terjadi dalam dunia pendidikan.

Pendidikan agama sangat perlu ditanamkan kepada anak-anak, bukan hanya sekedar mengasah intelektualnya tetapi membiasakannya melakukan hal-hal yang baik sehingga ini menjadi adabnya atau akhlak "ala bisa karena biasa". Untuk mencetak anak yang pintar dan saleh maka dibutuhkan kerjasama antara pendidik (muaddib), orang tua dan masyarakat. Tanpa peran ketiganya ini, mustahil mencetak generasi yang handal yang dapat melanjutkan syiar Islam.

Kewajiban dan tanggung jawab orang tua, guru (muaddib), dan masyarakat dapat dibagi dalam tiga garis besar, yakni pendidikan jasmaniah, aqliyah/intelektual, rohaniyah/spritual. Pendidikan jasmani berusaha bagaimana seorang anak tercukupi gizinya sehingga tidak menghambat pertumbuhan badannya. Sudah diperkenalkan olah raga dan manfaatnya, tidak menjadi anak yang hanya gemar main game dan nonton televisi. Pendidikan aqliyah, ialah pendidikan yang mengasah kecerdasan anak, anak sudah dibiasakan untuk kritis dan menggunakan akalnya. Bukan hanya anak yang pandai menghapal dan seragam dalam segala hal. Adapun pendidikan rohaniyah ialah menyangkut pembentukan kejiwaan, watak, budi pekerti dan segala sesuatu yang bersifat moral di dalam bidang akhlak dan aqidah (Pimpinan Pusat Muhammadiyah Majlis Tarjih,1972:25).

Anak yang memiliki seorang ibu yang cerdas (spiritual, intelektual dan emosional), maka akan berkembang menjadi pribadi yang sehat dan matang dalam menjalani kehidupannya. Oleh karena itu, seorang ibu perlu selalu menambah wawasan pendidikannya demi kepentingan membesarkan anak dan mendidik keluarganya menjadi keluarga yang bahagia dunia dan akhirat.

\section{KESIMPULAN}

Islam menuntun perubahan sosial ke arah yang lebih baik untuk pembangunan bangsa diartikan sebagai usaha memperbaiki tarap kehidupan bangsa secara spritual dan material, kualitatif dan kuantitatif, maka Islam mewajibkan partisipasi menyeluruh yakni laki-laki dan perempuan. Islam memandang segenap usaha untuk memperbaiki tarap kehidupan sebagai amal saleh, dan menjanjikan pengikutnya khalifah (kekuasaan) di bumi dengan menjalankan peran sebaik-baiknya. Khusus wanita sesuai dengan fitrah kewanitaannya, Islam menetapkan perananperanan tertentu bagi wanita dalam berbagai statusnya. Seperti telah dibahas dibagian pembahasan dimana wanita berperan sebagai istri yang salehah bagi suaminya, ibu yang selalu menjadi contoh tauladan bagi anak-anaknya dan menjadi tetangga yang menyenangkan dalam anggota masyarakat atau lingkungan sosial. Peranan seorang wanita dalam kehidupan memberikan dampak positif apabila dilakukan secara maksimal dan tidak meninggalkan kodratnya sebagai manusia umumnya dan perempuan secara khusus. Semoga dengan sentuhan tangan-tangan seorang istri/ibu, maka generasi selanjutnya akan membawa kehidupan lebih baik dalam keluarganya dan negaranya. $\left(^{*}\right)$ 


\section{REFERENSI}

Abd. Al-Rahim Umran, 1997, Family Planning in the Legacy of Islam, diterjemahkan oleh Muhammad Hasyim dengan Judul "Islam dan Keluarga Berencana”, Jakarta, Lentera.

Al-Baihaqi, Sunan Al Baihaqi Juz II h. 472.

Asghar Ali Engineer, 2003, The Qur'an Women and Modern Seciety, diterjemahkan oleh Akhmad Affandi dan Muh. Ihsan dengan judul "Matinya Perempuan Transformasi al-Quran, Perempuan dan Masyarakat Modern”, Yogyakarta, IRCiSoD.

Departemen Agama RI. 2009. Al-Qur'an dan Terjemahan. Jakarta.

Hamka, 1962, Lembaga Hidup, Djakarta, Djajamurni.

------, 1970, Falsafah Hidup, Djakarta, Djajamurni.

-------, 1972, Lembaga Budi, Djakarta, Djajamurni.

Husain Mazhahiri, 2002, Tarbiyyah ath-Thifl fi ar-Ru'yah al-Islamiyah, diterjemahkan oleh Segaf Abdillah Assegaf \& Miqdad Turkan, Jakarta, Lentera.

Jalaluddin Rahmat, 1986, Islam Alternatif, Bandung, Mizan.

Kekerasan pada Istri dalam rumah tangga, http://maureenlicious. wordpress.com /2011/04/28/ kekerasan-pada-istri-dalam-rumah-tangga.

Kris Budiman, 1999, Feminografi, Yogyakarta, Pustaka Pelajar.

Patmawati, tt., Makalab "Pengertian Akhlak dan Keutamaannya.

Pengertian Kekerasan Dalam Rumah Tangga, http://student.eepisits.edu/ wily/kewarganegaraan/ KEKERASAN \% 20 PADA \% 20 ISTRI \% 20 DALAM \% RUMAH \% TANGGA.html.

Pimpinan Pusat Muhammadiyah Majlis Tarjih, 1972, Adabul Mar'ah fil Islam, Yogyakrta, Majlis Tarjih Pimpinan Pusat Muhammadiyah.

Pusat Studi Wanita Pontianak. 2006. Koran Ibu.

Rianawati, 2001, Jurnal Khatulistiwa "Reinterpretasi Ajaran Islam tentang Wacana Perempuan", Pontianak, LP2M STAIN Pontianak.

Tips menanggulangi KDRT menurut Islam, http://ilalang.wordpress.com/2007/01/08/tipsmenanggulangi-kdrt-menurut-islam. 
Undang-undang Tentang Penghapusan KDRT No. 23 tahun 2004, Kenapa Laki-Laki Melakukan Tindakan Kekerasan Dalam Rumah Tangga (KDRT)? http://www.erwinmiradi.com/kenapa-laki-1... \#erwinmiradi.com.

Zohra Andi Baso, 2000, Langkah Perempuan Menuju Tegaknya Hak-hak Konsumen, Makassar, Yayasan Lembaga Konsumen Sulawesi Selatan. 